\title{
Nitrogen balance response to varying levels of dietary protein in slow-growing Windsnyer pigs
}

\author{
V.A. Hlatini ${ }^{1}$, C.N. Ncobela ${ }^{2} \&$ M. Chimonyo ${ }^{1 \#}$ \\ ${ }^{1}$ Animal and Poultry Science, University of KwaZulu-Natal, P/Bag X01, Scottsville 3209, Pietermaritzburg, South \\ Africa \\ ${ }^{2}$ Agricultural Research Council-Animal Production Institute, P/Bag X2, Irene 0062, South Africa
}

(Submitted 11 September 2109; Accepted 4 January 2020; Published 9 October 2020)

\author{
Copyright resides with the authors in terms of the Creative Commons Attribution 4.0 South African Licence. \\ See: http://creativecommons.org/licenses/by/4.0/za \\ Condition of use: The user may copy, distribute, transmit and adapt the work, but must recognise the authors and the South African \\ Journal of Animal Science.
}

\begin{abstract}
Protein requirements for slow-growing pigs have not been defined. The study was designed to determine the relationship between the level of dietary protein and nitrogen balance in slow-growing Windsnyer pigs. Thirty Windsnyer pigs with an initial bodyweight of $34.7(\mathrm{SD}=0.85) \mathrm{kg}$ were randomly assigned to six experimental diets containing 193,174, 154, 135, 117, and $97 \mathrm{~g} / \mathrm{kg}$ of crude protein (CP). Pigs were penned individually. There were five pigs in each diet. The faecal nitrogen output (NFO) showed a decreasing quadratic relationship with protein level. A linear relationship between protein level and urinary nitrogen excretion was observed $(P=0.0001)$. The total nitrogen excreted showed a significant quadratic relationship to decreasing levels of $\mathrm{CP}$ in the diets $(P=0.0001)$. The apparent digestibility of nitrogen had a linear relationship with dietary $\mathrm{CP}$ level $(P=0.0005)$. A quadratic relationship between dietary protein level and $\mathrm{N}$ utilization was observed $(P=0.0001)$. The optimum protein level for total nitrogen excreted, nitrogen utilization and biological value of feed protein were attained at $135 \mathrm{~g} / \mathrm{kg}$ protein level. The efficiency of nitrogen utilization supports the low protein diet. The present results suggest reducing the dietary protein level for Windsnyer pigs to decrease amount of excreted $\mathrm{N}$ that is deposited into the environment.
\end{abstract}

Keywords: apparent nitrogen digestibility, ideal protein level, nitrogen retention, excreted nitrogen, nitrogen utilization

\#Corresponding author: Chimonyo@ukzn.ac.za

\section{Introduction}

A large number of smallholder pig farmers in southern Africa keep slow-growing pigs (Ramsey et al., 2000; Chimonyo et al., 2006). Slow-growing Windsnyer pigs are indigenous pigs that are facing extinction and it is essential to conserve them through sustainable utilization. The commercial pig industry shuns slowgrowing breeds owing to their high propensity to deposit fat (Halimani et al., 2012). These indigenous pigs play a pivotal role in improving and maintaining financial sustainability and in reducing food insecurity (Ncobela et al., 2018). To strengthen the commercial value of Windsnyer pigs, their nutrient requirements need to be understood. One of the main limitations to Windsnyer pig production by smallholder farmers is the protein supply. Slow-growing pigs require CP levels of between 130 and $160 \mathrm{~g} / \mathrm{kg}$ (Vasupen et al., 2004). Other slow-growing genotypes, such as the Cinta Senese pigs (Sirtori et al., 2010), Mong Cai pigs (Pham et al., 2010), Moo Lath pigs (Phengsavanh \& Lindberg, 2013), Indian pigs (Paul et al., 2017), and Ghungroo pigs (Hazorika et al., 2017), have also provided evidence that their dietary protein requirements are much lower than those recommended by the NRC (2012). Dose-response trials are ideal in estimating protein requirements for these genotypes.

Dietary protein is an expensive nutrient that contributes immensely to the total cost of feed. Efficient utilization of protein depends on understanding the optimum levels that meet protein needs for growth, reproduction, and maintenance (Paul et al., 2007). An incorrect supply of protein is not ideal for optimal protein deposition and can be detrimental to pig performance (Whittemore et al., 2001; Noblet et al., 2004; Norgaard et al., 2014). For example, excess dietary protein increases nitrogen excretion through the urine (Carpenter et al., 2004). Precise dietary inclusion of protein also reduces $\mathrm{N}$ losses to the environment. 
The extent of utilization of dietary protein can be determined by measuring $\mathrm{N}$ balance (Noblet et al., 2001; Hlatini et al., 2017). The usual procedure is to regress nitrogen intake balance on intake and to define the requirement as the intake level that would produce a zero balance. Reduced nitrogen intake is an effective nutritional strategy in conservation efforts and assists in designing dietary supplementation programmes. Pigs often consume more dietary protein than the theoretical requirements based on nitrogen balance trials. A higher dietary protein supply results in positive $\mathrm{N}$ balance, excessive emission of $\mathrm{N}$ and undesired odours being emitted by pigs (Le et al., 2009; Kerr et al., 2014). Determining the precise dietary protein level is important for pig performance and environmental health (Noblet et al., 2001; Galassi et al., 2010; Norgaard et al., 2014).

Conservation efforts for Windsnyer pigs could be enhanced if their protein requirements were determined. The viability of satellite populations such as those at the Agricultural Research Council (ARC), Irene, Pretoria, are threatened by the high cost of feed. Pig producers who are interested in producing organic pork under extensive systems would require knowing appropriate dietary supplementation levels to enhance the profitability of pig enterprises. To assess nitrogen levels in the diet, nitrogen intake, utilization, and digestibility, retained nitrogen, excreted nitrogen, net protein utilization, including the biological value of feed protein, are used. Nitrogen retention is a more sensitive trait than average daily feed intake, average daily gain and feed conversion ratio (Figueroa et al., 2000). If the growth rate is low, a higher proportion of nitrogen is lost if nitrogen consumption exceeds requirements by a wide margin. There is great potential for using low-protein diets to reduce nitrogen excretion in slow-growing pigs. Low CP diets are achieved at the expense of soybean meal content. The strategy to reduce the excess excretion of nitrogen may involve matching CP requirements to the growth stage. Hence, it is critical to determine dietary protein levels for Windsnyer pigs to avoid an incorrect protein supply. The objective of the study was therefore to determine the nitrogen balance in Windsnyer pigs fed on various levels of dietary CP. It was hypothesized that the nitrogen balance would decrease linearly with a decrease in levels of CP in the diet.

\section{Materials and Methods}

The study was conducted at the ARC, Animal Production Institute (API), Irene, South Africa. The care and use of experimental animals were carried out according to the approved standards of the Animal Ethics Committee of the ARC-API (reference number APIEC 17/12).

Thirty clinically healthy two-month-old Windsnyer pigs from the same genetic and health status source were supplied by ARC. The trial sample size was in line with other nitrogen balance trials in pigs (Canh et al., 1998; Noblet et al., 2001; Otto et al., 2003; Accaiaioli et al., 2011). There is evidence that three to six animals per group[is a sufficient number for nitrogen balance trials in pigs (Canh et al., 1998; Noblet et al., 2001; Otto et al., 2003; Portejoie et al., 2004; Accaiaioli et al., 2011; Hazorika et al., 2018). The experimental pigs were ear-tagged and housed in a room with artificial heating, lighting, and proper ventilation systems. The ambient temperature and relative humidity were maintained at $24.5^{\circ} \mathrm{C}(\mathrm{SD}=1.9)$ and $62.7 \%(\mathrm{SD}=$ 15.07), respectively, were recorded every 15 minutes throughout the trial. Slow-growing pigs weighing about $34.7 \mathrm{~kg}(\mathrm{SD}=0.85)$ were allocated to six dietary treatments in a completely randomized design. There were five pigs in each of the six treatments. Each pig was treated as an experimental unit. The pigs were caged individually in pens measuring $1.5 \times 1 \mathrm{~m}$. Each pen was provided with water through a low-pressure nipple drinker, and feed was supplied in a self-feeder trough.

The treatments included six CP levels, namely 193.0, 173.7, 154.4, 135.1, 116.8, and $96.5 \mathrm{~g} / \mathrm{kg} \mathrm{CP}$, with five replications for each dietary treatment. A control diet was formulated according to CP standards for the experimental pigs as recommended by NRC (2012). To formulate the experimental diet, a $193 \mathrm{~g} / \mathrm{kg} \mathrm{DM}$ CP maize-soybean meal diet was formulated. Then each protein level was reduced by $10 \%$ of the control diet at the expense of soybean meal to reach the desired levels of $173.7,154.4,135.1,116.8$, and $96.5 \mathrm{~g} / \mathrm{kg}$ CP. Six diets were formulated to have similar net energy value of about $9.5 \mathrm{MJ} / \mathrm{kg}$. Feed and water were provided ad libitum. All six diets were formulated to meet or exceed NRC (2012) recommendations for all other nutrients and were supplied in mash form. The diets were formulated with the software program Bestmix ${ }^{\circledR}$ (Adifo), an advanced least-cost feed formulation. The ingredients were maize, wheat bran, soybean meal, oil sunflower, limestone, monocalcium phosphate, salt, lysine HCL, methionine, threonine, tryptophan, and mineral-vitamin premix. The ingredients and the nutrient profiles of the diets are given in Table 1. Diet samples were taken from all the feeders three days after the beginning and three days before the end of the experiment and kept in a cool dry place until they were homogenized and subsampled for chemical composition analyses.

Dry matter, ash, CP, and crude fat of the diets were determined using the standard AOAC (1990) methods. Nitrogen content was analysed following the Dumas combustion method in a Leco Truspec nitrogen analyser (St Joseph, MI, USA). A factor of 6.25 was used to calculate CP content. The neutral detergent fibre (NDF) and acid detergent fibre (ADF) were determined using ANKOM Fiber Analyser (Ankom Macedon, NY, 
USA) following methods by Van Soest et al. (1991). Acid hydrolyses were used for amino acid preparation before analyses with an amino acid analyser (SY-KAM, Erising, Germany). Samples for minerals were ashed at $450{ }^{\circ} \mathrm{C}$ and dissolved in $1 \mathrm{M} \mathrm{HCl}$ (Abdou et al., 2011). The major ingredients and chemical analyses of the experimental diet are given in Table 1.

Table 1 Ingredients and chemical composition of diets used in nitrogen balance study for slow-growing Windsnyer pigs

\begin{tabular}{|c|c|c|c|c|c|c|}
\hline \multirow{2}{*}{ Ingredient (g/kg) } & \multicolumn{6}{|c|}{ Levels of crude protein (g/kg DM) } \\
\hline & 193 & 174 & 154 & 135 & 116 & 97 \\
\hline Yellow maize & 602 & 633 & 688 & 725 & 767 & 720 \\
\hline Soya oil cake & 273 & 207 & 171 & 117 & 75.0 & 50.0 \\
\hline Wheat bran & 85.0 & 120 & 100 & 120 & 120 & 155 \\
\hline Limestone & 13.0 & 12.5 & 12.1 & 13.0 & 13.5 & 1.0 \\
\hline Monocalcium phosphate & 6.0 & 6.0 & 4.0 & 4.0 & 4.0 & 5.0 \\
\hline Sunflower oil & 5.0 & 5.0 & 5.0 & 5.0 & 5.0 & 5.0 \\
\hline Salt & 5.0 & 5.0 & 5.0 & 5.0 & 5.0 & 5.0 \\
\hline Lysine HCL & 3.8 & 3.8 & 3.8 & 3.8 & 3.8 & 2.0 \\
\hline Threonine & 1.1 & 1.1 & 1.1 & 1.1 & 1.1 & 1.0 \\
\hline Methionine & 1.1 & 1.0 & 1.0 & 1.0 & 1.0 & 0.75 \\
\hline Tryptophan & 0.2 & 0.2 & 0.2 & 0.2 & 0.2 & 0.2 \\
\hline Vitamin-mineral premix & 4.7 & 4.7 & 4.7 & 4.8 & 4.7 & 6 \\
\hline \multicolumn{7}{|l|}{ Calculated nutrient analysis } \\
\hline Dry matter & 884 & 883 & 882 & 880 & 879 & 881 \\
\hline Net energy value $(\mathrm{MJ} / \mathrm{kg})$ & 9.76 & 9.78 & 9.92 & 10.1 & 10.1 & 9.99 \\
\hline Crude protein & 192 & 169 & 153 & 137 & 117 & 100 \\
\hline Crude fibre & 27.3 & 28.6 & 25.9 & 26.4 & 25.3 & 27.3 \\
\hline Ash & 54.8 & 52.8 & 50.3 & 46.5 & 45.0 & 55.2 \\
\hline Fat & 37.2 & 38.0 & 38.2 & 39.0 & 39.4 & 44.1 \\
\hline \multicolumn{7}{|c|}{ Laboratory chemical analysis } \\
\hline Dry matter & 882 & 882 & 876 & 875 & 875 & 876 \\
\hline Crude protein & 202 & 177 & 161 & 145 & 121 & 103 \\
\hline Crude fat & 27.2 & 21.7 & 22.0 & 31.2 & 27.2 & 24.1 \\
\hline Neutral detergent fibre & 142 & 174 & 158 & 173 & 199 & 197 \\
\hline Acid detergent fibre & 44.2 & 50.5 & 47.2 & 47.8 & 45.3 & 46.5 \\
\hline Ash & 46.7 & 46.2 & 40.6 & 30.6 & 44.9 & 39.4 \\
\hline
\end{tabular}

The nitrogen balance trial was conducted with male pigs only to facilitate the collection of urine and faeces. The experiment lasted five days in week 6 . Urine and faecal collections were done each morning at 08h00 for five consecutive days. The hand-picking method was practised to completely collect faeces from the pens and place them in plastic bags. Faeces were collected over a 24-hour period from the edges of the pens and a 1-mm sieve was suspended underneath each pen to capture fallen faeces (Ouellet et al., 2004). At the end of the collection period, the faeces samples were mixed thoroughly, weighed, then two subsamples of $250 \mathrm{~g}$ for each of the six diets for thirty pigs were oven-dried at $60{ }^{\circ} \mathrm{C}$ overnight, and $1 \%$ formalin was added for conservation, pending analysis.

Plastic trays were positioned below pens to allow for the total collection of urine that would have oozed through a 1-mm sieve suspended underneath the pen of each pig. The urine was removed every day, weighed and placed in a clean container. To reduce the volatilization of nitrogenous compounds in the urine, 
$2 \mathrm{ml} 25 \%$ sulphuric acid was added to each tray within five minutes of collection. Post weighing of total urine collection, two subsamples of $250 \mathrm{ml}$ urine were taken for each of the six diets for analyses. Three hundred and sixty subsamples for faeces and urine samples were stored at $4{ }^{\circ} \mathrm{C}$, pending nitrogen analyses. The nitrogen content level of faeces and urine were determined according to the method described by Kjeldahl (AOAC, 1990). Nitrogen balance was therefore calculated as follows:

$$
\text { Apparent } N \text { digestibility }=\frac{N_{\text {consumed }}-N_{\text {excreted }}}{N_{\text {comsumed }}}
$$

where. $\mathrm{N}$ consumed $=\mathrm{DM}$ intake $\times \mathrm{N}$-content $t_{\text {feed }}$, and $\mathrm{N}$ excreted $=\mathrm{DM}$ excreta output $\times \mathrm{N}$-content excreta. $_{\text {. }}$ These equations were used to determine $\mathrm{N}$ retention, $\mathrm{N}$ digestibility, $\mathrm{N}$ retained and $\mathrm{N}$ utilization:

$$
\begin{gathered}
N \text { retained }=\text { consumed } N-\text { faecal } N-\text { urinary } N \\
N \text { digested }=\text { consumed } N-\text { faecal } N \\
\% N \text { digestibility }=\frac{N \text { digested }}{\text { consumed } N} \times 100 \\
N \text { retained }=N \text { digested }- \text { urinary } N \\
\% N \text { utilization }=\frac{N \text { retained }}{\text { consumed } N} \\
\text { Net protein utilization }=\frac{N \text { retained }}{\text { consumed } N} \\
\text { Biological value of protein }=\frac{N \text { retained }}{N \text { digested }}
\end{gathered}
$$

The data were analysed with the procedures of SAS (SAS Institute, Inc., Cary, North Carolina, USA). PROC UNIVARIATE was used to determine the normality of the data for nitrogen balance parameters. The data were normally distributed. PROC MEANS was used to determine the mean \pm standard error for the influence of dietary protein level on nitrogen balance. Response surface regression (PROC RSREG) was used to determine the relationship between dietary protein level and nitrogen balance parameters.

The regression model used was:

$$
Y=\beta_{0}+\beta_{1} L+\beta_{2} L^{2}+e,
$$

where: $Y$ is the response variable (N retention, $\mathrm{N}$ digestibility, urinary $\mathrm{N}$, faecal $\mathrm{N}, \mathrm{N}$ intake and urinary $\mathrm{N}$ : faecal $\mathrm{N}$ ratio), $\beta_{0}+\beta_{1}+\beta_{2}$ are regression coefficients, $L$ is the $\mathrm{CP}$ inclusion level, and $e$ is the residual error.

Subsequently, a piecewise regression (broken-stick) analysis using PROC NLIN was used to determine the optimum inclusion levels of dietary protein on nitrogen balance. A level of $P<0.05$ was chosen as the criterion for statistical significance. The piecewise regression model was:

$$
\begin{array}{ll}
Y_{j}=\beta_{1} X+K_{1} & \text { for } x<x_{c} \\
Y_{k}=\left(K_{1}+x_{c}\left(\beta_{1}-\beta_{2}\right)\right)+\beta_{2 X} & \text { for } x>x_{c}
\end{array}
$$

where: $x$ is the CP level in the diet, $Y$ is the response variable, $K_{1}$ is the intercept of the linear function when the CP inclusion level affects nitrogen balance $\left(\mathrm{i}, \mathrm{e}\right.$, ; the term $\left(K_{1}+x_{c}\left(\beta_{1}-\beta_{2}\right)\right)$ is the intercept when the level of $\mathrm{CP}$ in the diet exceeds the optimal level $\left(x_{c}\right)$; and $\beta_{1}$ and $\beta_{2}$ are the estimates of slope for the respective segments.

\section{Results}

The pigs experienced no health issues or feed refusal during the experimental period. The relationships between dietary protein levels and nitrogen balance parameters are shown in Table 2. Nitrogen intake decreased when dietary CP level decreased $(P=0.0001)$. Nitrogen excretion via faeces had a decreasing quadratic effect $(P=0.005)$. There was a linear response in nitrogen $(\mathrm{N})$ excreted via urine as dietary protein decreased $(P=0.0001)$. Total $\mathrm{N}$ excreted showed a quadratic relationship to decreasing levels of $\mathrm{CP}$ in the diets $(P=0.0001)$. The amount of $\mathrm{N}$ absorbed decreased linearly with reducing dietary protein levels $(P=0.0001)$ (Table 2$)$. 
Table 2 Relationship between dietary protein level and nitrogen balance parameters in slow-growing Windsnyer pigs

\begin{tabular}{|c|c|c|c|c|c|c|c|c|c|c|}
\hline \multirow{2}{*}{ Item } & \multicolumn{6}{|c|}{ Dietary crude protein level g/kg DM } & \multirow{2}{*}{ SD } & \multicolumn{2}{|c|}{ Regression coefficient } & \multirow[b]{2}{*}{$P$-value } \\
\hline & 193 & 174 & 154 & 135 & 116 & 97 & & Linear & Quadratic & \\
\hline $\mathrm{N}$ intake $\mathrm{g} / \mathrm{d}$ & 38.10 & 37.10 & 30.10 & 24.2 & 26.5 & 17.5 & 0.05 & $2.44 \pm 1.31$ & & 0.0001 \\
\hline $\mathrm{NFO} \mathrm{g} / \mathrm{d}$ & 3.06 & 3.10 & 2.74 & 4.52 & 2.97 & 2.38 & 0.63 & & $-0.0388 \pm 0.013$ & 0.0050 \\
\hline $\mathrm{NUO} \mathrm{g} / \mathrm{d}$ & 2.06 & 3.27 & 3.11 & 3.36 & 0.58 & 0.50 & 0.83 & $2.584 \pm 0.395$ & & 0.0001 \\
\hline Total N losses $\mathrm{g} / \mathrm{d}$ & 5.08 & 6.37 & 5.85 & 7.88 & 3.55 & 2.88 & 0.94 & $3.733 \pm 0.607$ & $-0.12 \pm 0.02$ & 0.0001 \\
\hline $\mathrm{N}$ retention $(\mathrm{g})$ & 33.10 & 30.7 & 24.20 & 16.3 & 23.0 & 14.6 & 0.94 & $-1.29 \pm 1.775$ & & 0.0001 \\
\hline $\mathrm{N}$ absorbed g/d & 35.10 & 34.0 & 27.40 & 19.7 & 23.5 & 15.1 & 0.63 & $1.293 \pm 1.498$ & & 0.0001 \\
\hline Apparent N digestibility & 0.92 & 0.92 & 0.91 & 0.81 & 0.89 & 0.86 & 0.03 & $-0.025 \pm 0.018$ & & 0.0005 \\
\hline $\mathrm{NU} \%$ & 86.70 & 82.8 & 80.60 & 67.4 & 86.6 & 83.6 & 3.43 & & $0.430 \pm 0.11$ & 0.0001 \\
\hline Net protein utilization & 0.87 & 0.83 & 0.81 & 0.67 & 0.87 & 0.84 & 0.04 & & $0.0043 \pm 0.0011$ & 0.0005 \\
\hline BVFP & 0.94 & 0.91 & 0.89 & 0.83 & 0.98 & 0.97 & 0.03 & $-1.144 \pm 0.021$ & $0.00384 \pm 0.00073$ & 0.0001 \\
\hline N digestibility \% & 92.10 & 91.70 & 90.90 & 81.3 & 88.8 & 86.4 & 2.52 & $2.50 \pm 1.79$ & & 0.0005 \\
\hline
\end{tabular}

SD: standard deviation; NFO: nitrogen faecal output; NUO: nitrogen urine output; N: nitrogen; NU: nitrogen utilization; BVFP: biological value of feed protein 
There was a linear relationship between reduced dietary protein level against apparent digestibility of nitrogen and digestibility of nitrogen as percentage $(P=0.0005)$. As the dietary protein level decreased, so did apparent nitrogen digestibility together with nitrogen digestibility. Nitrogen retention showed a linear relationship with varying levels of protein in the diet $(P=0.0001)$. As the level of CP decreased, so did nitrogen retention. A quadratic relationship was observed between dietary protein level and nitrogen utilization $(P=0.0001)$. As the level of $\mathrm{CP}$ in the diet decreased, nitrogen utilization increased accordingly (Figure 1). There was a quadratic relationship between inclusion level of CP and net protein utilization $(P$ $=0.0005$ ). Decreasing dietary protein level from $193 \mathrm{~g} / \mathrm{kg}$ to $135 \mathrm{~g} / \mathrm{kg}$ decreased net protein utilization which increased again below that level of dietary protein. The quadratic relationship between the level of CP and the biological value of feed protein was highly significant indicting $(P=0.0001)$ indicating an intermediate minimum. The apparent biological value of protein decreased before it began to increase as the dietary protein level decreased (Figure 1).

The optimal protein level was reached when further decrease in protein resulted in no change on nitrogen balance parameters (Table 3). The optimum NFO 3.04 occurred at $119.7 \mathrm{~g} / \mathrm{kg}$ protein level $(P$ $=0.0169$ ). Using broken-stick methods, the threshold value for total nitrogen excreted was estimated to be at $143.9 \mathrm{~g} / \mathrm{kg}$ protein level, and the plateau at $6.11(P=0.0003)$. The broken-stick analyses were used to estimate the threshold values for nitrogen utilization and biological value of feed protein, which were obtained at 140.6 and $141.5 \mathrm{~g} / \mathrm{kg}$ protein level, and the plateau at 70 and 0.77 , respectively $(P=0.050)$.

\section{Discussion}

The supply of dietary protein according to the growth stage is important to improve the efficiency of nitrogen utilization in slow-growing Windsnyer pigs. The efficiency of protein utilization by pigs depends on the dietary composition and the growth stage of the animal (Noblet et al., 2001; Whittemore et al., 2001; Dourmad et al., 2013). A low CP diet results in a reduction in the amount of nitrogen excreted (Deng et al., 2007; Dourmad et al., 2013). The present results with Windsnyer pigs demonstrated that reducing levels of dietary protein resulted in a reduction in total nitrogen excretion. Noblet et al. (2001) reported that reducing CP level (189 - $123 \mathrm{~g} / \mathrm{kg}$ ) could decrease nitrogen excretion by $10 \%$ for each percentage of protein dropped. The present results agree with earlier reports (Canh et al., 1998; Portejoie et al., 2004; Deng et al., 2007; Hernandez et al., 2011). However, these studies were conducted on fast-growing pigs.

Reducing the level of CP by a $7.7 \%$ and $9.7 \%$ unit reduced urinary nitrogen excretion by $71.6 \%$ and $75.8 \%$ and total nitrogen excretion by $30.2 \%$ and $43.4 \%$, respectively. In the current study, there was a linear decrease in urinary nitrogen excretion as dietary CP level decreased. The results agree with earlier results in modern pigs (Canh et al., 1998; Le Bellego \& Noblet 2002; Portejoie et al., 2004; Deng et al., 2007; Hernandez et al., 2011; Dourma et al., 2013). Slow-growing Cinta Senese pigs fed diets with increasing dietary protein level from 70 to $160 \mathrm{~g} / \mathrm{kg}$, showed an increasing trend of urinary nitrogen excretion (Acciaioli et al., 2011). A decrease was reported (Hernandez et al., 2011) in urinary nitrogen excretion as the dietary $\mathrm{CP}$ decreased from 150 to $135 \mathrm{~g} / \mathrm{kg} \mathrm{CP}$ in the slurry of growing pigs. In addition, a strong correlation was reported between urinary nitrogen excretion and dietary CP intake (Pfeiffer et al.., 1995).

The relationship between urinary nitrogen excretion and dietary protein level was closer than that of nitrogen excretion in faeces and level of $\mathrm{CP}$ in the diet. A reduction in urinary nitrogen as dietary protein decreased from 165 to $125 \mathrm{~g} / \mathrm{kg}$ was reported earlier (Canh et al., 1998). Reduced urinary nitrogen excretion was seen in rabbits as the protein level was reduced $(180-140 \mathrm{~g} / \mathrm{kg})$. The decreased amount of total nitrogen excreted was influenced largely by the reduction in urinary excretion (Portejoie et al., 2004). Reduced nitrogen excretion and nitrogen loss demonstrate proper animal feeding and management. Lowered dietary CP level, together with increased content of fibre, resulted in a reduction in the excretion of nitrogen through faeces. Nitrogen excretion in the urine is preferable, considering that the high amount of the nitrogen in waste is excreted in the faeces.

The positive quadratic effect on nitrogen excretion through faeces as dietary protein level decreased was associated with nitrogen absorbed. Reducing dietary CP levels decreased faecal excretion by $7.8 \%, 18.7 \%$, $9.9 \%, 11.6 \%$, and $29.2 \%$, urinary excretion by $27.7 \%, 31.2 \%, 54.5 \%, 87.1 \%$, and $88.9 \%$, and total nitrogen excreted by $19.2 \%, 25.8 \%, 35.5 \%, 54.9 \%$, and $63.5 \%$, respectively. The quadratic response on faecal nitrogen content when pigs fed decreasing CP levels remains unclear. Further research is needed to understand the reasons. The shift in nitrogen excretion from urine to faeces at a lower level of CP could be associated with dietary fibre content. Galassi et al. (2010) reported that reduced dietary CP level from 120 to $98 \mathrm{~g} / \mathrm{kg}$ with a high fibre level $(200 \mathrm{~g} / \mathrm{kg})$ led to reduced excretion of $\mathrm{N}$ into the slurry. The low protein diets in the study were formulated to contain increased levels of fibre. 


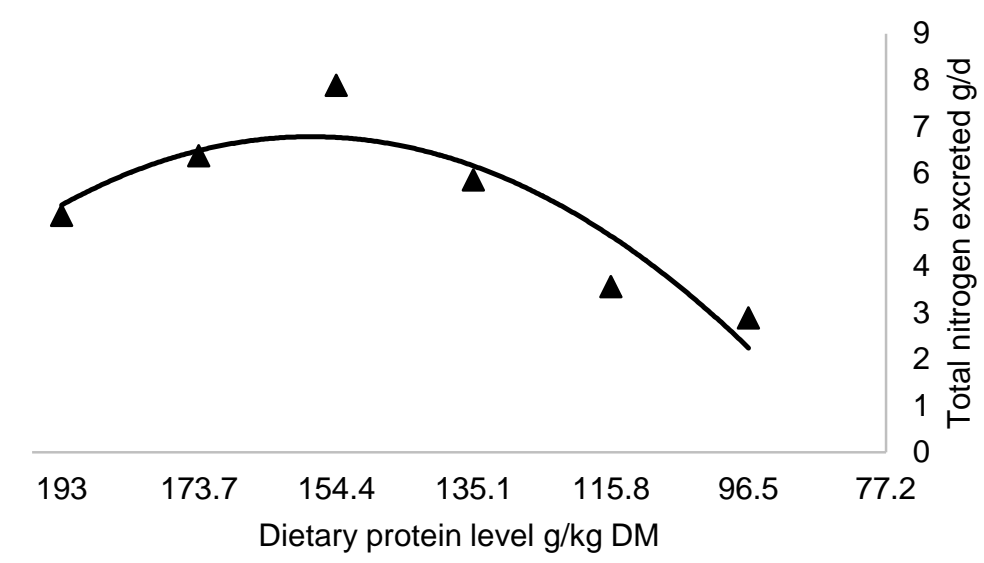

a)

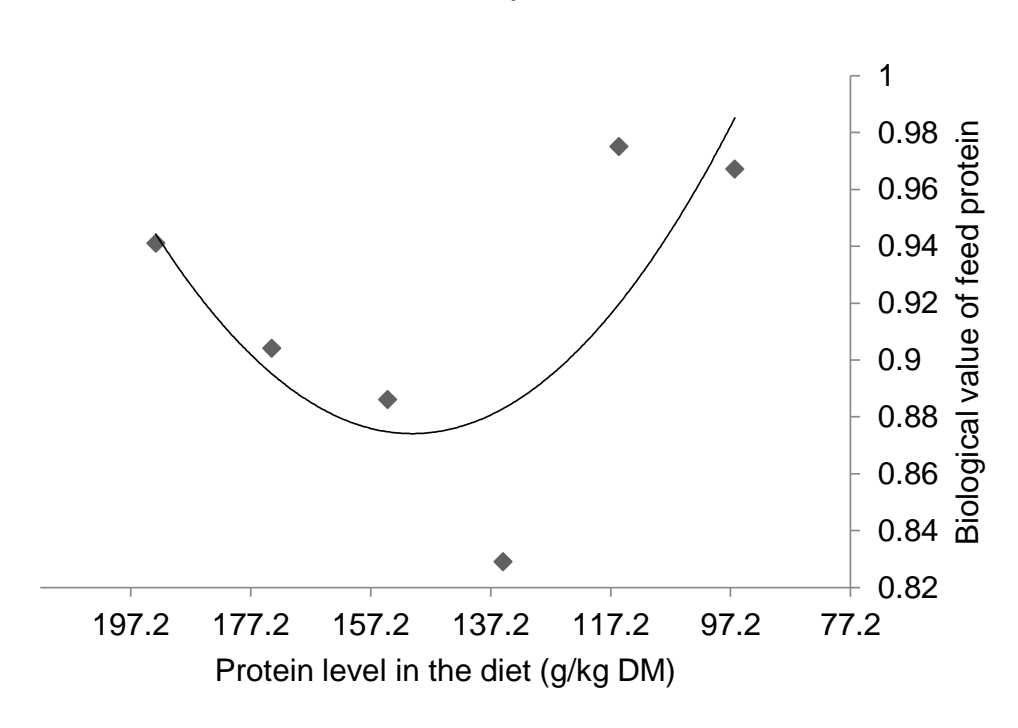

c)

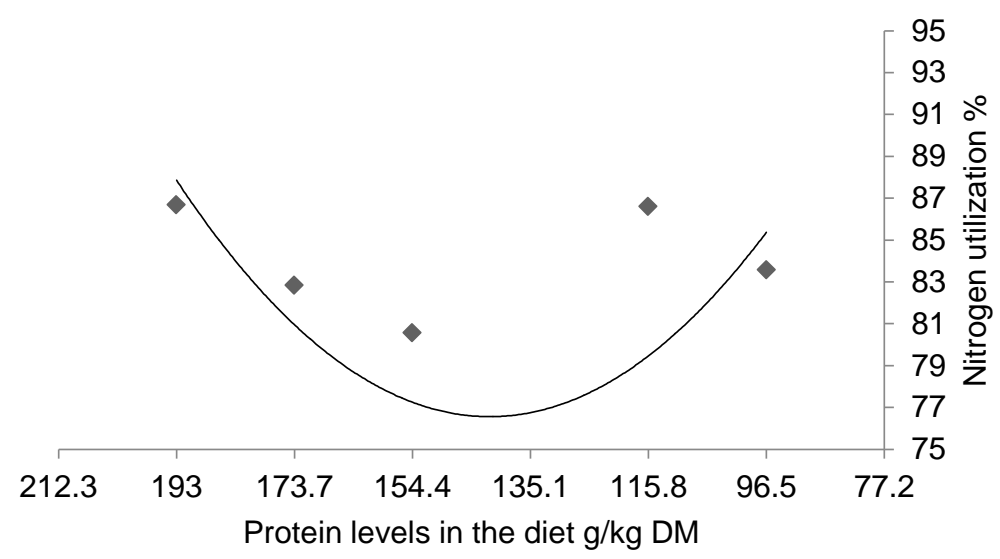

b)

Figure 1 Relationship between dietary protein levels and total nitrogen excretion, nitrogen utilization and biological value of feed protein in Windsnyer pigs 
Table 3 Optimal dietary protein levels at which a further decrease in protein constrained faecal nitrogen excretion, total nitrogen excretion, nitrogen utilization and biological value of feed protein in slow-growing Windsnyer pigs

\begin{tabular}{|c|c|c|c|c|c|c|c|c|c|}
\hline \multirow[b]{2}{*}{ Item } & \multicolumn{2}{|c|}{$K_{1}$} & \multicolumn{2}{|c|}{$\beta_{1}$} & \multicolumn{2}{|c|}{$\beta_{2}$} & \multirow[b]{2}{*}{ Join-point $(x c)$} & \multirow[b]{2}{*}{ Plateau } & \multirow[b]{2}{*}{$P$-value } \\
\hline & Estimate & SD & Estimate & SD & Estimate & SD & & & \\
\hline Faecal nitrogen excretion & -2.72 & 87.5 & -1.57 & 21 & -0.11 & 1.25 & 119.7 & 3.04 & 0.0169 \\
\hline Total nitrogen excretion & 2.45 & 30.1 & -1.49 & 9.05 & -0.15 & 0.65 & 143.9 & 6.11 & 0.0003 \\
\hline Nitrogen utilization & 86.50 & 354 & 6.24 & 103 & 0.60 & 0.70 & 140.6 & 70.14 & 0.2420 \\
\hline Biological value of feed protein & 1.01 & 3.4 & 0.09 & 1 & 0.01 & 0.05 & 141.5 & 0.774 & 0.0500 \\
\hline
\end{tabular}

$K_{1}$ : is the intercept of the piecewise regression, $\beta_{1}$ : rate of change of the piecewise regression when the item value $<x c, \beta_{2}$ : rate of change when of the piecewise regression when the item value $>X C$, xc: estimated join-point of the piecewise regression, SD: standard deviation 
An increase in wheat bran also contributed to nitrogen excretion through faeces. Similar results were obtained by Gidenne et al. (2013), who reported that reduced protein level (177 - $139 \mathrm{~g} / \mathrm{kg}$ ) and increased fibre $(179-216 \mathrm{~g} / \mathrm{kg})$ shifted the nitrogen excreted from the urine to the faeces. Galassin et al. (2010) reported that pigs fed diets containing protein levels of 122 and $98 \mathrm{~g} / \mathrm{kg}$ with fibre levels of $200 \mathrm{~g} / \mathrm{kg}$ fibre excreted more nitrogen in faeces. Dietary fibre level decreased the nitrogen excreted in urine and shifted nitrogen excretion to the faeces. These results are preferred to reduce ammonia volatilization (Portejoie et al., 2004). Reducing urinary nitrogen excretion in pigs is critical to prevent pig the industry from contributing highly to environmental pollution. Nitrogen is excreted via urine as urea, which is the primary precursor of ammonia volatilization (Canh et al., 1998). The present results suggest that diets with low levels of protein reduce urinary nitrogen excretion and ammonia volatilization. The present results agree with earlier reports that indicated that decreasing dietary protein levels reduces total nitrogen excretion because of lower nitrogen excretion in the urine (Canh et al., 1998; Acciaoli et al., 2011).

The linear decrease in nitrogen retention, nitrogen absorbed, apparent nitrogen digestibility and retained nitrogen as dietary protein level decreased could be due to the reduction of the protein intake. The results suggest that when the percentage unit of dietary CP increased, nitrogen retention also increased. Acciaioli et al. (2011) reported that increasing the dietary CP level from 70 to $160 \mathrm{~g} / \mathrm{kg}$ led to an increase in nitrogen balance parameters in slow-growing Cinta Senese pigs. The decrease in dietary CP led to decreases in the nitrogen absorbed and nitrogen retained (Portejoie et al., 2004; Acciaioili et al., 2011). However, Portejoie et al. used diets with a high CP level of between 145 and $250 \mathrm{~g} / \mathrm{kg}$ and Acciaioili et al used heavy slow-growing pigs $(62.7 \mathrm{~kg})$, which are much higher than the levels and different from the types of pigs used here. Zervas and Zijisha (2002) reported that when pigs with a bodyweight of about $32 \mathrm{~kg}$ were fed reduced dietary protein from 197 to $138 \mathrm{~g} / \mathrm{kg} \mathrm{DM}$, nitrogen retention decreased with dietary protein level. The higher values of nitrogen retention show balanced dietary amino acids, while low values indicated less digestible CP and enlarged endogenous protein loss (Drew et al., 2012; Hang, 1998). Nitrogen intake has a significant influence in the resulting nitrogen retained by the pig. A higher nitrogen intake is likely to increase the amount of nitrogen retained (Acciaoli et al., 2011; Dourma et al., 2013).

The linear reduction in apparent nitrogen digestibility and nitrogen digestibility percentage in response to reduced dietary protein level agreed with earlier reports (Portejoie et al., 2004; Deng et al., 2007). Apparent nitrogen digestibility and nitrogen retention was reduced by dietary CP reduction from 165 to 125 $\mathrm{g} / \mathrm{kg}$ in fast-growing pigs (Canh et al., 1998). The low protein diets were formulated by decreasing the level of soybean meal. This decrease resulted in a reduction in dietary nitrogen digestibility, because soybean meal is the most digestible feed ingredient for pigs in the current formulated diet (CVB, 1994; Gatel \& Grosjean, 1999).

There was a decreasing, increasing quadratic effect in nitrogen utilization, net protein utilization (NPU) and biological value of feed protein (BVFP) as dietary protein level decreased. A quadratic effect in nitrogen utilization as dietary CP level decreased agreed with a study by Carpenter et al. (2004). The present results demonstrated adequate intake of protein and availability for digestibility in the small intestine. The Windsnyer pigs that were fed the diets with a lower dietary protein utilized nitrogen better, which indicated less excretion of nitrogen into the environment. The present results are important in decreasing the amount of excreted nitrogen that is deposited into the environment, mainly in the urine (Noblet et al., 2001; Acciaioili et al., 2011; Dourmad et al., 2013;). A decrease in total nitrogen excretion indicates an improvement in nitrogen utilization of the diet (Monteiro et al., 2010). The limitations to understanding the nitrogen balance in slow-growing pigs include the challenges of determining miscellaneous nitrogen losses precisely. The small number of pigs per treatment limited the study and was not enough when establishing equations. The possibility of nitrogen volatilization from the urine before the collection period could affect the accuracy of the nitrogen balance study, which also depends on whether the nitrogen content in the diet could entirely be found in the experimental animal.

\section{Conclusion}

The level of dietary protein has an impact on nitrogen excretion in slow-growing pigs. Based on the nitrogen balance data, a dietary CP level of $135 \mathrm{~g} / \mathrm{kg}$ was suitable for Windsnyer pigs. Thus, protein levels in pig diets formulated for a slow-growing genotype can be reduced to obtain a decreased excretion of $\mathrm{N}$ into the environment.

\section{Acknowledgements}

The authors thank the UKZN competitive grant and National Research Foundation for funding this research (grant number; 102702).

\section{Authors' Contributions}


$\mathrm{VAH}$ and MC designed the study, collected and analysed the data, drafted and revised the manuscript. NCN collected the data and revised the manuscript.

\section{Conflict of Interest Declaration}

The authors declare that there was no conflict of interest.

\section{References}

Abdou, N., Nsahlai, I.V. \& Chimonyo, M. 2011. Effect of groundnut haulms supplementation on millet stover intake, digestibility and growth performance. Anim. Feed Sci. Tech. 169, 176-184. https://doi.org/10.1016/j.anifeedsci.2011.07.002

AOAC, 1990. Official methods of analysis. 15th edition. Association of Official Analytical Chemists, Arlington, VA.

AOAC, 2000. Official methods of analysis of AOAC International. Method 984.13. 17th edition. Journal of AOAC International, Gaithersburg, MD.

Acciaioli, A., Sirtori, F., Pianaccioli, L., Campodoni, G., Pugliese, C., Bozzi, R. \& Franci, O., 2011. Comparison of total tract digestibility and nitrogen balance between Cinta Senese and Large White pigs fed on different levels of dietary crude protein. Anim. Feed Sci. Tech. 169, 134-139. https://doi.org/10.1016/j.anifeedsci.2011.05.009

Canh, T.T., Aarnink, A.J.A., Schutte, J.B., Sutton, A., Langhout, D.J. \& Verstegen, M.W., 1998. Dietary protein affects nitrogen excretion and ammonia emission from slurry of growing-finishing pigs. Lvstck. Prod. Sci. 56,181-191. https://doi.org/10.1016/S0301-6226(98)00156-0

Carpenter, D.A., O'Mara, F.P. \& O'Doherty, J.V., 2004. The effect of dietary crude protein concentration on growth performance, carcass composition and nitrogen excretion in entire grower-finisher pigs. Irish J. Agric. Food Res. 43(2), 227-236. https://www.jstor.org/stable/25562520

Centraal Veevoederbureau, 1994. Data about chemical composition, digestibility and feeding value of feedstuffs. Veevoedertabel, Centraal Veevoederbureau, Lelystad, The Netherlands.

Chimonyo, M., Dzama, K. \& Bhebhe, E., 2006. Genetic determination of individual birth weight, litter weight and litter size in Mukota pigs. Lvstck. Sci. 105, 69-77. https://doi.org/10.1016/j.livsci.2006.04.034

Deng, D., Huang, R.L., Li, T.J., Wu, G.Y., Xie, M.Y., Tang, Z.R., Kang, P., Zhang, Y.M., Fan, M.Z., Kong, X.F., Ruan, Z., Xiong, H., Deng, Z.Y. \& Yin, Y.-L., 2007. Nitrogen balance in barrows fed low-protein diets supplemented with essential amino acids. Lvstck. Sci. 109, 220-223. https://doi.org/10.1016/j.livsci.2007.01.122

Figueroa, J., Lewis, A. \& Miller, P.S., 2000. Nitrogen balance and growth trials with pigs fed low-crude protein, amino acid-supplemented diets. University of Nebraska Lincoln. Animal Science Department. Swine Reports 110. https://digitalcommons.unl.edu/coopext_swine/110

Gatel, F. \& Grosjean, F., 1992. Effect of protein content of the diet on nitrogen excretion by pigs. Lvstck. Prod. Sci. 31, 109-120. https://doi.org/10.1016/0301-6226(92)90059-D

Galassi, G., Colombini, S., Malagutti, L., Crovetto, G.M. \& Rapetti, L., 2010. Effects of high fibre and low protein diets on performance, digestibility, nitrogen excretion and ammonia emission in the heavy pig. Anim. Feed Sci. Tech. 161, 140-148. https://doi.org/10.1016/j.anifeedsci.2010.08.009

Gidenne, T., Combes, S. \& Fortun-Lamothe, L., 2013. Protein replacement by digestible fibre in the diet of growing rabbits. 1: Impact on digestive balance, nitrogen excretion and microbial activity. Anim. Feed Sci. Tech.183, 132141. https://doi.org/10.1016/j.anifeedsci.2013.04.022

Halimani, T.E., Muchadeyi, F.C., Chimonyo, M. \& Dzama, K., 2012. Opportunities for conservation and utilisation of local pig breeds in low-input production systems in Zimbabwe and South Africa. Trop. Anim. Health Prod. Sci. 45, 8190. DOI: 10.1007/s11250-012-0177-2

Hansen, M.J., Nørgaard, J.V., Adamsen, A.P.S. \& Poulsen, H.D., 2014. Effect of reduced crude protein on ammonia, methane, and chemical odorants emitted from pig houses. Lvstck. Sci. 169, 118-124. https://doi.org/10.1016/j.livsci.2014.08.017

Hernández, F., Martínez, S., López, C., Megías, M.D., López, M. \& Madrid, J., 2011. Effect of dietary crude protein levels in a commercial range, on the nitrogen balance, ammonia emission and pollutant characteristics of slurry in fattening pigs. Animal 5, 1290-1298. https://doi.org/10.1017/S1751731111000115

Hlatini, V.A., Zindove, T.J. \& Chimonyo, M., 2017. The influence of polyethylene glycol inclusion in Vachellia tortilis leaf meal on nitrogen balance in growing pigs. S. Afr. J. Anim. Sci. 47, $298-306$. http://dx.doi.org/10.4314/sajas.v47i3.6

Kanengoni, A.T., Chimonyo, M., Erlwanger, K.H., Ndimba, B.K. \& Dzama, K., 2014. Growth performance, blood metabolic responses, and carcass characteristics of grower and finisher South African Windsnyer-type indigenous and Large White $x$ Landrace crossbred pigs fed diets containing ensiled corncobs. J. Anim. Sci. 92, 5739-5748. https://doi.org/10.2527/jas.2014-8067

Kerr, B.J., Ziemer, C.J., Trabue, L., Crouse, J.D. \& Parkin, T.B., 2006. Manure composition of swine as affected by dietary protein and cellulose concentrations. J. Anim. Sci. 84, 1584-1592. https://doi.org/10.2527/2006.8461584x

Le Bellego, L. \& Noblet, J. 2002. Performance and utilization of dietary energy and amino acids in piglets fed low protein diets. Lvstck. Prod. Sci. 76, 45-58. https://doi.org/10.1016/S0301-6226(02)00008-8

Le Bellego, L., Van Milgen, J., Dubois, S. \& Noblet, J. 2001. Energy utilization of low-protein diets in growing pigs. J. Anim. Sci. 79, 1259-1271. https://doi.org/10.2527/2001.7951259x 
Leek, A.B.G., Callan, J.J., Henry, R.W. \& O'Doherty, J.V., 2005. The application of low crude protein wheat-soya bean diets to growing and finishing pigs, the effects on nutrient digestibility, nitrogen excretion, faecal volatile fatty acid concentration and ammonia emission from boars, Irish J. Agric. Food Res. 44, $247-260$. https://www.jstor.org/stable/25562551

National Research Council (NRC), 1998. Nutrient requirements of swine. National Academies Press, Washington DC.

National Research Council (NRC), 2012. Nutrient requirements of swine. National Academies Press, Washington DC.

Ncobela, C.N., Kanengoni, A.T., Thomas, R.S. \& Chimonyo, M., 2018. Voluntary feed intake and growth performance of slow-growing pigs fed on increasing levels of ensiled potato hash meal. Trop. Anim. Health Prod. 50, 113-120. https://doi.org/10.1007/s11250-017-1410-9

Noblet, J., Le Bellego, L., Van Milgen, J. \& Dubois, S., 2001. Effects of reduced dietary protein level and fat addition on heat production and nitrogen and energy balance in growing pigs. Anim. Res. 50, $227-238$. https://doi.org/10.1051/animres:2001129

Nørgaard, J.V., Hansen, M.J., Soumeh, E.A., Adamsen, A.P.S. \& Poulsen, H.D., 2014. Effect of protein level on performance, nitrogen utilisation and carcass composition in finisher pigs. Acta Agriculturae Scandinavica. Section A - Anim. Sci. 64(2), 123-129. https://doi.org/10.1080/09064702.2014.943280

Otto, E.R., Yokoyama, M., Ku, P.K., Ames, N.K. \& Trottier, N.L., 2003. Nitrogen balance and ileal amino acid digestibility in growing pigs fed diets reduced in protein concentration. J Anim. Sci. 81, 1743-1753. https://doi.org/10.2527/2003.8171743x

Ouellet, D.R., Petit, H.V., Veira, D. \& Charmley, E., 2004. Estimation of faecal output, digestibility, and intake using a controlled release capsule of alkanes in early and late lactation dairy cows fed two levels of concentrate. Can. J. Anim. Sci. 84, 277-289. https://doi.org/10.4141/A03-041

Paul, S.S., Mandal, A.B., Chatterjee, P.N., Bhar, R., \& Pathak, N.N., 2007. Determination of nutrient requirements for growth and maintenance of growing pigs under tropical conditions. Animal 1, $269-282$. https://doi.org/10.1017/S1751731107284228

Pfeiffer, A. Henkel, H. Verstegen, M.W.A. \& Philipczyk. I.,1995. The influence of protein intake on water balance, flow rate and apparent digestibility of nutrients at the distal ileum in growing pigs. Lvstck. Prod. Sci. 44, 179-187. https://doi.org/10.1016/0301-6226(95)00070-4

Phengsavanh, P. \& Lindberg, J.E., 2013. Effects of dietary protein levels on growth performance and feed intake in native Moo Lath Lao pigs. J. Anim. Vet. Adv. 12, 406-411. DOI: 10.36478/javaa.2013.406.411

Portejoie, S.J.Y., Dourmad, J.Y., Martinez, J. \& Lebreton, Y. 2004. Effect of lowering dietary crude protein on nitrogen excretion, manure composition and ammonia emission from fattening pigs. Lvstck. Prod. Sci. 91, 45-55. https://doi.org/10.1016/j.livprodsci.2004.06.013

Ramsey, K., Smuts, M. \& Els, H.C. 2000. Adding value to South African landrace breeds conservation through utilisation. Agric. Res. 27, 9-15. https://doi.org/10.1017/S1014233900001243

Sirtori, F., Acciaioli, A., Pugliese, C., Bozzi, R., Campodoni, G. \& Franci, O., 2010. Effect of dietary protein level (as substitution of maize with soybean meal) on growth rate and feed efficiency of Cinta Senese pig in the growingfattening period. Ital. J. Anim. Sci. 9, 30. DOI: 10.4081/ijas.2010.e30

Van Soest, P.J., Robertson, J.B. \& Lewis, B.A.,1991. Methods for dietary fibre, neutral detergent fibre and non-starch polysaccharides in relation to animal nutrition. J. Dairy Sci. 74, $3583-3597$. DOI: 10.3168/jds.S00220302(91)78551-2

Vasupen, K.C., Sarnklong, C., Yuangklang, S., Wongsuthavas, S., Srinanaun, P. \& Keson, P. 2004. Effect of dietary protein levels on growth performance of native swine in Sakon Nakhon Province. Agricultural seminar. Dept. Anim. Sci., Khon Kaen University, Thailand. pp. 599-605.

Whittemore, C.T., Green, D.M. \& Knap, P.W., 2001. Technical review of the energy and protein requirements of growing pigs: Protein. Anim. Sci. 73, 363-373. https://doi.org/10.1017/S1357729800058331

Zervas, S. \& Zijlstra, R.T., 2002. Effects of dietary protein and oathull fiber on nitrogen excretion patterns and postprandial plasma urea profiles in growing pigs. J. Anim. Sci. 80, 3238-3246. https://doi.org/10.2527/2002.80123238x 